\title{
Sexuality politics on the football field: queering the field in Turkey
}

\author{
Deniz Nihan Aktan
}

\begin{abstract}
Focusing on queer-identified amateur football teams, this article investigates the potentials of the mobilities and alliances of gender non-conforming footballing people to disrupt the seemingly effortless structure of the football field. While football is arguably one of the sports with the strongest discriminatory attitudes toward gender non-conforming people, it has also become a site of resistance for queers in Turkey as of 2015. How political opposition groups relate to the football field, which is mostly considered as a male-dominant and heterosexualized space where social norms are reproduced, are classified into three groups in my research: resistance through, against, and for football. I give particular attention to the category "resistance for football" as a distinctive way for gender non-conforming people to inhabit the field. I discuss how the link between sexual and spatial orientations shapes the domain of what a body can do, both in terms of normativity and capacity, and I explore what these teams offer in order to exceed spatial and sexual boundaries. Lastly, I present recent queer interventions in the value system of the game through which I reflect upon the concept of "queer commons" and the processes of bonding, belonging, and border-making in queer communities.
\end{abstract}

Keywords: LGBTI+ Sports; Queer; Sexuality; Football; Turkey

\section{Introduction}

The women's football league in Turkey was suspended by the Turkish Football Federation (TFF) for three seasons in 2003. The TFF announced the decision with the headline, "for a healthy league," and thus a restructuring process was started. More than 200 football players found themselves without

Deniz Nihan Aktan, Global Cultures Program, Bologna University, 40126, Via Zamboni 33, Bologna, Italy; deniznihanaktan@gmail.com

Author's Note: The author would like to thank the anonymous reviewers for their constructive comments. I also thank Cenk Özbay for his priceless support since the very beginning of this process. 
a club and the certifications of players were canceled. Among the reasons given for this suspension there were rumors of lesbian affairs, mismanagement, abuse by trainers, and lack of interest. ${ }^{1}$ Even though a woman's league had started in 1994 thanks to a variety of developments at the national and international level, the tension between the image of a woman playing football and the gendered and gendering expectations in a heteronormative society was difficult to resolve and it led to the league getting to the point of suspension. ${ }^{2}$ The very moment I learned this hidden part of football history in Turkey, I realized that it was a story that I wanted to trace in more detail. This story, which has resonated with my personal life as well, was one among many examples of how extensively and intensively the link between sexuality and football has been constructed and thus regulates bodily actions on many different levels, from a child playing in a small neighborhood to the mega-events within far-reaching institutions.

In this article I investigate the potentials of the football field as a site of resistance mainly through the mobilities of gender non-conforming footballing people $^{3}$ in Turkey's amateur football field. Given that football is arguably one of the sports with the strongest discriminatory attitudes toward diverse genders and sexualities, ${ }^{4}$ it is striking to see that queer sports have flourished in the amateur football field. The amateur queer football scene in Turkey is incipient but increasingly visible and gaining recognition as a new site of resistance for the LGBTI+ movement in Turkey, in a climate of increasing social and political repression. ${ }^{5}$ Focusing on the queer-identified amateur teams that have emerged in the past several years in several metropolises around Turkey, I analyze this recent interest in the football field within

1 Pınar Öztürk, "Kadın Futbolcuların Futbol Alanındaki Deneyimleri," unpublished PhD dissertation, Hacettepe University, 2017.

2 Haber Vitrini, "Bayan Futbol Liginde Lezbiyenlik Skandalı," December 26, 2003, http://www. habervitrini.com/spor/bayan-futbol-liginde-lezbiyenlik-skandali-97636, accessed October 12, 2019.

3 Throughout the text I use the phrase "gender non-conforming people," sometimes interchangeably with "non-conforming people," for all individuals who experience discrimination and exclusion based on their sexuality (be it a gay man, a trans person, a cisgender woman, or a cisgender straight man who does not perform masculinity) and thus cannot conform to the conditions of the football field.

4 See: Öztürk, "Kadın Futbolcuların Futbol Alanındaki Deneyimleri"; Kari Fasting, "Sporda Cinsel Taciz ve İstismar," in Oyunun Ötesinde, edited by İ. Hacısoftaoğlu, F. Akcan, and N. Bulgu, 211-30 (Istanbul: Nota Bene, 2015); Gertrud Pfister, "Avrupa Perspektifinden Toplumsal Cinsiyet ve Spora Ilişkin Gelişmeler ve Mevcut Sorunlara bir bakış," in Oyunun Ötesinde, 159-86; Lale Orta, "Women and Football in Turkey," International Journal of Humanities and Social Science 47, no. 1 (2014): 85-93; Katie Liston, "Sport and Gender Relations," Sport in Society 9, no. 4 (2006): 616-33.

5 See: Kerem Öktem and Karabekir Akkoyunlu, "Exit from Democracy: Illiberal Governance in Turkey and beyond," Southeast European and Black Sea Studies 16, no. 4 (2016): 469-80; Yağmur Nuhrat, "Contesting Love through Commodification," American Ethnologist 45, no. 3 (2018): 392-404; Cenk Özbay et al., The Making of Neoliberal Turkey (London: Routledge, 2016); and Human Rights Watch, "Turkey Events of 2018," 2019, https://www.hrw.org/world-report/2019/country-chapters/ turkey, accessed October 12, 2019. 
the broader scope of dispersion and decentralization of the resistance, and I argue that this site of sexuality politics as a new spatial orientation harbors the potential for creative and unconventional (inter)actions for the bodies inside.

In my research I propose three non-mutually exclusive ways in which political opposition groups treat the football field as a site of resistance, namely they resist against football, resist through football, and resist for football. By "resist against football," I mean that there are groups that oppose the current manifestation of the football field. By "resist through football," I argue that there are teams that use the football field as an instrument for conveying their political claims to the wider public. As for the last category, "resist for football," it refers to the desire and struggle for being able to play football, which might be claimed to be the most fundamental one. While the examples for the first two categories are easy to find in the actions of all the political opposition groups, ${ }^{6} \mathrm{I}$ argue that the last one is distinctive for gender non-conforming footballing people. Queer-identified amateur football teams in Turkey fall into this category since they labor over the basics of the long-established game to create new corporeal and spatial orientations.

The word field, which is presumably the most frequently used word in this text, is intended to have multiple meanings throughout my research. First, as the title suggests, it is an area where the physical activity of football is performed by two teams and with the necessary equipment. When I write the "football field," I also refer to the structural domain which produces and impacts the relations and the rules inside, and this gives the word its second sense. Third, I consider this sporting branch as my academic field of study; therefore I also refer to the domain in which football-related knowledge is produced. Finally, drawing upon Bourdieu's conceptualization, I consider the field, with all the other meanings that I have just counted, as a contested space with relative autonomy which thus risks reproducing social norms but also harbors potentials for struggle. ${ }^{7}$

Below I give contextual and historical background to gender- and sexuality-based discrimination in the football field, introduce my research fieldwork, and reflect on my insider position in parallel with a broader methodological discussion. The main section of the article consists of four parts. (1) I discuss why the amateur football field has become a site of resistance in the last decade for women and queers in Turkey. (2) I investigate the multiple types of connections that political opposition groups establish with the football field. In the remaining two parts I focus on the

6 See the section "Categories of resistance: against, through, for" for further elaboration.

7 Pierre Bourdieu, Distinction: A Social Critique of the Judgement of Taste (London: Routledge, 1984). 
gender non-conforming people who resist for football. (3) I explore how the link between sexual and spatial orientations shapes the domain of what a body can do, both in terms of normativity and capacity, and why the discourse of scalable inclusion ${ }^{8}$ falls short of explaining the orientation of gender non-conforming people toward football. (4) I present recent queer interventions in the value system of the game through which I have a chance to reflect upon the concept of "queer commons" and processes of bonding, belonging, and border-making in queer communities.

\section{Mapping the field: contextual background}

The cisgender white heterosexual male embracing "hegemonic masculinity" has been the main character in the domain of sports since the earliest efforts to ensure that modern sports have universalized standards wherever they are played, to ensure a level playing field. Under these conditions the mere participation of gender non-conforming people in sports indicates a constant effort to exceed the constituent borders that keep being reproduced through sports institutions, discriminating discourses by sports authorities, and misrepresentations in the media. ${ }^{9}$ We regularly witness ruptures and non-linear changes in the participation level of women in certain sports, both in the careers of individual athletes and in mass exclusions.

Besnier et al. claim that "the exclusion of women from a particular sport is often more a result of cultural definitions of a sport as 'masculine' and less a result of women's physiological inability to compete," though the latter is also used as a justification for exclusion. The authors add that this dualistic understanding is a constitutive element of modern sports, with reference to how Coubertin, the founder of the modern Olympic Games, was against women's participation in sports. ${ }^{10}$

8 I describe the conventional discourse of inclusion as "scalable inclusion" drawing upon the term "scalability" that is defined by Tsing as "the ability to expand - and expand, and expand - without rethinking basic elements" (Anna Tsing, "On Nonscalability: The Living World Is Not Amenable to Precision-Nested Scales," Common Knowledge 18, no. 3 [2012]: 505-24, 505). The gender non-conforming people who resist for football are not satisfied with this kind of inclusion that does not allow for self-determination.

9 See Canan Koca, "Cinsiyetlendirilmiş Bir Sosyal Alan Olarak Spor," in Sporun Toplumsal Cinsiyet Halleri, edited by Canan Koca, 18-37 (Ankara: Spor Yayınevi, 2016); Tess Kay and Ruth Jeanes, "Women, Sport and Gender Inequity," in Sport and Society: A Student Introduction, edited by B. Houlihan and D. Malcolm, 130-54 (London: Sage, 2015); Jorge Knijnik, "Femininities and Masculinities in Brazilian Women's Football: Resistance and Compliance," Journal of International Women's Studies, 16, no. 3 (2015): 54-70; Jennifer Hargreaves, Sporting Females: Critical Issues in the History and Sociology of Women's Sports (London: Routledge, 1994).

10 Niko Besnier, Susan Brownell, S., and Thomas F. Carter, The Anthropology of Sport: Bodies, Borders, Biopolitics (Oakland: University of California Press, 2018), 144-5. 
Even though the beginning of modern football for all genders dates back to the second half of the nineteenth century in many parts of the world, predominantly due to colonization and overseas commerce, the progress of women's football has been quite intermittent. Including some of the leading countries of today's football such as Brazil, Germany, and England, the institutional organization of women's football was halted for many decades due to the sexist and hostile attitude of football federations toward women playing football. ${ }^{11}$ At the beginning of the 1970s, developments in women's football accelerated again.

In Turkey, entering sports fields, as is the case with many other public spaces, has been much easier for men; in the early Republican period the limited number of women in sports included those from non-Muslim minorities or the daughters of elite supporters of modernization. The motivation for allowing women in was related primarily to attempts at regulating women's bodies in harmony with modern gender roles, securing the reproduction of healthy generations, and demonstrating a harmonious and healthy society through mass sports events such as Gymnastics Fest. ${ }^{12}$ The first women's football teams in Turkey, İzmir Women Football and İstanbul Women Football Team, were formed in $1954 ;{ }^{13}$ nevertheless, the Women's Football League only started in 1994. The league is just another example of the interrupted journey of women's football around the world since the teams in the league and even the league itself shut down from time to time for various reasons, including mismanagement, corruption, rumors of lesbianism, and not winning enough games. ${ }^{14}$

According to FIFA's Member Associations Survey Report, ${ }^{15}$ more than thirteen million women were playing association football in the world as of 2019. These players experience numerous problems such as financial difficulties, sexual abuse, homo/trans/biphobia, and institutional sexism. These problems are also shared by women football players in Turkey ${ }^{16}$ Öztürk states that the TFF has considered women's football to be a social project since 2006. While this has led to a remarkable increase in the number of women football

11 Öztürk, "Kadın Futbolcuların Futbol Alanındaki Deneyimleri," 16-17.

12 Betül Yarar, "Modernleşmenin Gerilimlerle Dolu Kimliği: Modern Türkiye Tarihinde Hem Kadın Hem Sporcu Olmak," in Oyunun Ötesinde, edited by Ilknur Hacısoftaoğlu, Funda Akcan, and Nefise Bulgu, 187-210 (İstanbul: Nota Bene, 2015); Sertaç Sehlikoglu, "Sports: Turkey," in Encyclopedia of Women and Islamic Cultures, Vol. 14, edited by Suad Joseph and Elora Shehabuddin (Leiden: Brill, 2017).

13 Lale Orta, "Women and Football in Turkey," International Journal of Humanities and Social Science 47, no. 1 (2014): 85-93. See also "Futbol Kadını Bozar mı," April 4, 2016, http://www.5harfliler.com/futbolkadini-bozar-mi/, accessed July 18, 2020.

14 Öztürk, "Kadın Futbolcuların Futbol Alanındaki Deneyimleri."

15 FIFA, "Women's Football: Member Associations Survey Report," 2019, https://img.fifa.com/image/ upload/nq3ensohyxpuxovcovj0.pdf, accessed December 12, 2019.

16 According to the same report, 98,560 women are playing association football in Turkey. 
players and has inspired women's teams in many cities, Öztürk problematizes this institution-level attitude of the male-dominant football domain, arguing that the athletic skills of the players, the quality of the game, and international competitions become of secondary importance. Moreover, describing women's games as a social responsibility project reproduces the gendered structure of the field and limits the expectations of players. ${ }^{17}$

Outside the institutional borders of football there is another football scene in Turkey where LGBTI+ people come together and form amateur teams. There has been a remarkable increase in the number of independent leagues and teams in the last couple of years. With the significant influence of the Gezi Uprising on the coming together of a variety of political opposition groups, gender-mixed alternative football leagues ${ }^{18}$ have emerged in the last couple of years. Around the same period, queer-identified amateur teams were also formed one after another inside these leagues or independently of them. Today there is a growing number of queer-identified teams in many cities. ${ }^{19}$ Among them are Lezyonerler, Atletik Dildoa, and Queerpool in İstanbul; Sportif Lezbon in Ankara; Muamma in Mersin; and Lolitop in Kocaeli. ${ }^{20}$

Besides the obvious crucial struggle against sexual discrimination in football, the queer-identified amateur football teams deserve particular attention because they intervene in the taken-for-granted rules and configurations of the game itself to open up new possibilities. Concluding this section, I feel the need for a clear analytical distinction. This recently emerging queer-identified amateur football field shows that football is no longer an exclusive space for cisgender straight men as women's experiences in the professional field have demonstrated for decades; therefore, I find it crucial to start from women's football to historicize and describe my research field. Despite this recognition, it should be clear that women's football and queer football are two different categories and one should not interpret the former category as the precursor of the latter given the extensive and ongoing

17 Öztürk, "Kadın Futbolcuların Futbol Alanındaki Deneyimleri."

18 Karşı Lig and Özgür Lig are the most visible ones and they are still active. See their Facebook pages respectively: Karşı Lig, https://www.facebook.com/karsilig/; and Özgür Lig, https://www.facebook. com/OzgurLigAnkara/, accessed December 12, 2019.

19 All these teams have emerged in metropolitan areas where LGBTI+ communities have more spaces in terms of political activities and socialization. A broader discussion about the city could enrich the analysis with further arguments on the conditions that set the ground for the emergence of these teams.

20 As one may notice, the names of these queer-identified teams often combine cultural elements of queer culture with witty humor. Atletik Dildoa and Sportif Lezbon play with the names of two famous football clubs, Athletic Bilbao and Sporting Lisbon. The word "muamma" means "enigma" in Turkish and the players of this team adopt this name to claim that gender is an enigma. "Lolitop" combines the words "lollipop" and "top;" the latter means ball and queers reclaim this word although it is used in society in a pejorative manner for gay people. 
homophobia in the TFF. ${ }^{21}$ Therefore, while my research acknowledges the struggle of women footballers in the professional field and its overlapping aspects with my field, my focus is entirely on the sexuality politics of queer-identified amateur football teams. I find it extremely important to pursue the footsteps of these gender non-conforming people on the football field, claiming that those who cannot follow the predetermined path are the ones who can find new ways, methods, and communities that are otherwise forgotten or thrown aside. ${ }^{22}$

\section{Methodology: being in the field}

This study is based primarily on twelve in-depth interviews with the players of five different queer-identified amateur teams from İstanbul and Ankara, along with my first-hand experiences and observations as an insider. Three teams that are currently active in Mersin, Kocaeli, and İstanbul have been formed after I completed my interviews; therefore their players are not represented as interviewees in my study. Nevertheless, their contributions to queer athlete-activism and their individual experiences have undoubtedly enriched this study. My position as an insider smoothed the way for me to reach out to players who would be willing to be interviewed. As expected, it was easy to arrange meetings with my teammates. I reached out to players from other teams either directly or through intermediary personal contacts, rarely through mobile or social media profiles but mostly by asking face to face in sports events where we came together. Another positive aspect of being an insider was that we could have intimate and deeper conversations during the interviews. As I have changed my interviewees' names for the sake of confidentiality, all the names I provide here are pseudonyms.

Since the first day of this study my researcher self and my everyday self have been intertwined in a way where I found myself observing every move that other players and I made on the football field through an ethnographic lens. A significant amount of the ethnographic data came into existence through the effortful processes in which I also took part as a football player. This enabled me to access a first-hand account of events, but at the same time it raised the question of whether I could interpret the context from a distance. Similar to my feeling of being in my ethnographic field whenever I entered the football

21 Öztürk, "Kadın Futbolcuların Futbol Alanındaki Deneyimleri." See also "Futbolun Kadınla İmtihanı," June 30, 2009, http://www.radikal.com.tr/yazarlar/tanil-bora/futbolun-kadinla-imtihani-942886/, accessed July 24, 2020.

22 Sara Ahmed, Queer Phenomenology: Orientations, Objects, Others (Durham, NC: Duke University Press, 2006); Jack Halberstam, The Queer Art of Failure (Durham, NC: Duke University Press, 2011). 
field, I often thought about how my research, the statistical data that I came across, and my arguments could contribute to our community. I shared my new insights plenty of times with my teammates and also with anonymous people via our team's Facebook page; we sometimes used this information and arguments in our public announcements and press bulletins.

While it is common, especially in the research done by marginalized communities, for an outsider to see no harm in intruding on people's private lives and asking the most intimate questions with no ethical concern, being a native in the field might also result in a variety of problems mainly due to what O'Reilly calls "over-rapport." ${ }^{23}$ As I have also seen in my case, an insider position provides several advantages such as gaining trust and acceptance more easily; creating a space of dialogue for further co-operations within the community; and being attentive to nuances, and thus more likely to prevent biased stereotypes. It is undeniable that "shared marginalization" provides the researcher with easier access to the field, however this per se does not promise an accurate analysis or a politically correct ethnography. ${ }^{24}$ In addition to these factors, an insider researcher is more inclined to feel overburdened with ethical contradictions, and responsibility for and commitment to the community, since they are too involved in the field, whereas an outsider might protect their assumedly neutral position.

Throughout my research I had to modify the scope of the field and to update the content several times since I was moving inside such a brand new and fast-growing field. Although I can foresee certain shortcomings of studying a very recent phenomenon, it has been quite an eye-opener for me to witness every moment of the process of how a field creates its own rules, limits, discourse, ethics, and humor in relation to changing external dynamics.

The way I use the word "woman" in the text is not limited to the hegemonic and normative womanhood which has the characteristics of being white, cisgender, straight, able-bodied, feminine, and belonging to the middle-upper social class. This image represents only one of the combinations among many diverse forms of womanhood and I, on the contrary, use the word with all the possible meanings one can attach to it in their self-identification process. If so, why do I use phrases "women and queers," "women and LGBTI+ people," and "women and gender non-conforming people" in the text? Do I intend to say that the categories of "women" and the other terms are mutually exclusive so that someone who defines herself as a woman is no longer queer? Furthermore, do I mean that the gender non-conforming body is never a

23 Karen O'Reilly, Key Concepts in Ethnography (London: Sage, 2008).

24 Aihwa Ong, "Women out of China: Traveling Tales and Traveling Theories in Postcolonial Feminism," in Women Writing Culture, edited by Ruth Behar and Deborah A. Gordon, 350-72 (Berkeley: University of California Press, 1995). 
woman and all women always conform with the norms? Of course not. These would not only unfairly exclude countless experiences of womanhood but also would fail to notice where these categories overlap. The reason why I specify both categories in all these phrases is to avoid sloppy clusters that would erase certain particularities, especially when the study is mostly about the particularities which are located at the intersection points of these categories.

The field of critical studies on sexualities has already made remarkable contributions to our way of thinking on gender and sexuality and it is undoubtedly a vital channel for looking at sporting people. ${ }^{25}$ Nuhrat problematizes the fact that women in male-dominated sports fields have been analyzed only through their relations with hegemonic masculinity, whether they embrace masculinity or femininity. ${ }^{26}$ This criticism is followed by the suggestion of a pluralistic understanding of masculinities and femininities: there are multiple and elaborate ways in which women struggle for their space in sports, and they should be meticulously approached. I take this suggestion seriously in my research since the sexuality politics of gender non-conforming footballing people is an intricate field of analysis of which interpretation through singular and fixed categories of sexuality remains insufficient.

\section{A (new) site of resistance}

Football, often defined as "the opium of the masses" for being highly influenced by state and market regulations, ${ }^{27}$ has been perceived as a social sphere in which sexism and homo/trans/biphobia were inherent. The structural exclusion of gender non-conforming people and sexist and discriminating discourses that prevail even in the moments of resistance have impeded many people from entering the field to play football let alone claim it as a site of resistance. It is a "sport that everyone knows but which we cannot play," says

25 Jayne Caudwell, "Queering the Field? The Complexities of Sexuality within a Lesbian-Identified Football Team in England," Gender, Place \& Culture 14, no. 2 (2007): 183-96; Mariann Vaczi, "Dangerous Liaisons, Fatal Women: The Fear and Fantasy of Soccer Wives and Girlfriends in Spain," International Review for the Sociology of Sport 51, no. 3 (2016): 299-313; Michael A. Robidoux, "Historical Interpretations of First Nations Masculinity and Its Influence on Canada's Sport Heritage," The International Journal of the History of Sport 23, no. 2 (2006): 267-84; Scarlett Drury, "Gay Sports Spaces: Transgressing Hetero (/Homo) Normativity and Transforming Sport?" in The Routledge Handbook of Sport, Gender and Sexuality, edited by Jennifer Hargreaves and Eric Anderson, 309-17 (New York: Routledge, 2014).

26 Yağmur Nuhrat, "The Violence Law and the Governmentalization of Football in Turkey," in The Making of Neoliberal Turkey, edited by Cenk Özbay, Maral Erol, Z. Umut Türem, and Ayşecan Terzioğlu, 83-96 (London: Routledge, 2016).

27 John Horne, Sport in Consumer Culture (Palgrave, 2005); Joseph Maguire, Power and Global Sport (London: Routledge, 2005). 
Funda, ${ }^{28}$ speaking about the widely accepted patriarchal environment of football. Even though sports, and football in particular, have always had the potential of being a site of resistance as a contested space, in Turkey it is the first time that such diverse political opposition groups have organized to play together and raise their voices on the football field.

\section{A new site for queer happenings}

Popularity and accessibility of football were two of the most common answers from my interviewees to the question of why the football field has been adopted by women and queers as a site of resistance. The intriguing paradox of the field was another reason suggested in the interviews: as one of the spaces where performances and discourses of toxic masculinity, sexism, and homo/ trans/biphobia are circulated the most, it also provides a relatively comfortable environment for the masculine performance of gender non-conforming people.

Adding the temporal dimension has led me to several other answers. The increase in the influence area and visibility of the LGBTI+ movement in Turkey, as well as the interactions in the Gezi Uprising, made queers one of the main actors of the newly emerging alternative football field. In Gezi, where the fan clubs of three big football teams of İstanbul came together under the name of Istanbul United, interactions and solidarity among different groups were established more than ever. Feminist Tent and the LGBT Blok, as two of the most visible groups in the park, held a workshop with the fan groups and thus intervened in the sexist discourses circulating in the resistance language: slogans that position the rival (opponent team or the state power) as "penetrated" (feminine) and themselves as "penetrator" (masculine).

Several gender-mixed amateur leagues and many anti-sexist teams emerged after Gezi, mainly in İstanbul and Ankara. The argument that the Gezi Uprising was an impetus for people to head for the football fields found a voice in my interviews. Funda: "I started going to matches right after Gezi and I thought a lot about it. This desire was always there but until Gezi told me 'come on, you are going there,' I didn't care about it." Ediz ${ }^{29}$ claims that the increase in the popularity of LGBTI+ community during Gezi might have facilitated the entrance of queers to the football field: "Think about the people who joined Pride March to take a selfie. It was kind of an advertisement and I think that it was a result of Gezi."

The Gezi Uprising was also significant because it furnished a large part of society with abundant knowledge and the instruments necessary to create

28 Interviewee 1: a lesbian football player in one of the queer-identified teams.

29 Interviewee 2: a lesbian football player in one of the queer-identified teams. 
alternative ways and spaces of collectivity and resistance. Nilgün ${ }^{30}$ ironically interprets the dispersion of political activities as related to the fact that "our state taught us to be political in every sense [...] They do not allow us to be in a certain space, they do not allow us to be in Taksim Square or Kizilay Square. Then we will meet in neighborhoods, be it a football field or a park, not necessarily a square." The call for the 2016 Pride March, after the violent police attack of the previous year and the most crowded marches in the LGBTI+ history of Turkey in 2013 and 2014, was witty and controversial: "We Are Dispersing!" 31 It was an unusual resistance that had no central point and it undoubtedly carried the traces of Gezi memory.

Before 2013, the male-dominant atmosphere of the football field, including the left-wing fan communities, was not challenged in such an organized manner. Here the case of Halil Ïbrahim Dinçdağ stands out as an exception. In 2009, his license as a football referee was not renewed because of a health report which exempted him from compulsory military service: the Turkish army considers homosexuality a psychosexual disorder. ${ }^{32}$ When Dinçdağ lost his job he filed a lawsuit against the TFF, and in the process he became a public figure. In 2015, he finally won the case and interpreted this result as a victory for the struggle against homophobia in Turkey. ${ }^{33}$ During that period, solidarity matches and discussions on football and homophobia were organized ${ }^{34}$ This is worth noting as a significant event for LGBTI+ people, who have long considered football as the field of the perpetrator.

\section{Categories of resistance: against, through, for}

In parallel with all the above, I argue that the football field has emerged as one of the alternative spaces, especially for gender non-conforming people, in the process of dispersion and proliferation of resistance after Gezi. Doing research on the struggle of women and queers against structural obstacles in the field showed me that the ways in which political opposition groups take to the football field vary and thus they should be analyzed in different categories. I propose three non-mutually exclusive forms in which political opposition

30 Interviewee 3: a lesbian football player in one of the queer-identified teams.

31 "Istanbul LGBTI+ Pride Committee Statement: We are Dispersing!" June 24, 2016, https:// LGBTInewsturkey.com/2016/06/24/istanbul-LGBTI-pride-committee-statement-we-are-dispersing/, accessed October 12, 2019.

32 Burcu Karakaş and Bawer Çakır, Erkeklik Ofsayta Düşünce (istanbul: iletişim, 2013).

33 Hurriyet, "Halil İbrahim Dinçdağ TFF'ye Açtığı Davayı Kazandı," December 29, 2015, http://www. hurriyet.com.tr/halil-ibrahim-dincdag-tffye-actigi-davayi-kazandi-40033252, accessed October 12, 2019.

34 "Eşcinselliğin Mücadele Alanı Olarak Futbol," December 14, 2013, http://bianet.org/biamag/lgbti/ 152047-escinselligin-mucadele-alani-olarak-futbol, accessed October 12, 2019. 
groups treat the football field as a site of resistance: resist against football, through football, and for football. By "resist against football," I mean that there are groups that oppose the current manifestation of the football field. By "resist through football," I argue that there are teams that use the football field as an instrument for conveying their political claims to the wider public. As for the last category, "resist for football," it refers to the desire and struggle for being able to play football, which might be claimed to be the most fundamental one. After I elaborate on the first two categories, I particularly focus on the distinct orientation of queer-identified amateur football teams in the last one. I investigate why the first two categories remain insufficient in explaining the relationship between gender non-conforming people and the football field, drawing upon the relevant literature on the link between corporeal, sexual, and spatial orientations.

\section{Resist against football}

The groups who resist against the current manifestation of football presume an essence and often advocate for bringing back that essence. I argue that the "essence" of football is discursively formulated in two predominant ways: the first group refers to the neutrality of the presumed essence and criticizes the commercialization and over-politicization of the game, stating that "it is just a game." The second group instead acknowledges that football has never been value-free but asserts that its values are inherently good and they should be restored. While the recognition of the diversity in the second formulation is visible in its slogan "football unites people," it has the risk of erasing "differences that matter" 35 since it lacks a critical reflection on the power relations and structural inequalities within the field.

Besnier remains skeptical about the neutrality of the game in itself and claims that it is always the locus of a colonial perspective, "with a specific morality, worldview, and gendering." 36 Football is constituted in a way that the people who want to play the game are obliged to comply with certain rules and limits; we witness the exclusion of particular groups as a result of non-compliance. The rituals of association football restrain and regulate the behaviors of people on the field; moreover, the regulated behaviors are not limited to the game-related movements.

35 Sara Ahmed, cited in Umut Erel, Jin Haritaworn, Encarnación Gutiérrez Rodríguez, and Christian Klesse, "On the Depoliticisation of Intersectionality Talk: Conceptualising Multiple Oppressions in Critical Sexuality Studies," in Theorizing Intersectionality and Sexuality, ed. Y. Taylor, S. Hines, and M. E. Casey, 56-77. (Palgrave Macmillan, London, 2010), 283.

36 Niko Besnier, "Sports, Bodies, and Futures: An Epilogue," The Contemporary Pacific 26, no. 2, (2014): 436. 
In the current football scene in Turkey it is almost impossible for a certified player to react against the militarist practices circulating in the field, to be critical about the dominant masculine and/or nationalist discourses, to be open about their sexual orientation if they are not straight, ${ }^{37}$ or to survive in the field without choosing one of the two genders. For instance, a KurdishGerman football player, Deniz Naki, received many threats during his career in Turkey based on his support for the Kurdish struggle and his criticisms of the Turkish state. He left Gençlerbirliği after being beaten in the street by three men who shouted racist remarks, and then he moved to Diyarbakır to play for Amed SK. While he was playing there he dedicated a team victory to the Kurdish struggle via his social media account, which caused the TFF to ban him for three years and six months from all competitive matches for spreading "separatist and ideological propaganda." 38

The historicization of modern football shows that it was a playground for power holders from the beginning and therefore has always been a site of resistance. For queer-identified teams, however, claiming the right to the field is not properly a reclamation since sexuality-based discrimination often prevails even in the moments of resistance. Semra ${ }^{39}$ recounts her experience in an alternative mixed league:

Playing in the same team or the same league increases the level of tolerance toward each other. However, not everything is settled; the patriarchal mentality is not completely erased. In one of the games, we were playing with four women and the opponent team had four men on the field. When we were leading the game, they stopped passing the ball to women in their team to beat us. That is why we did not have fun in this game.

Funda has the same feeling of frustration; she states: "I want to come together with people who have the same feelings and same motives. I do not want to spend my energy to transform the environment of a mixed league." As it is not simply a comeback and not a demand for scalable inclusion, therefore, the analysis of the entrance of queers to the field requires a different perspective.

37 As mentioned in the introduction, the TFF shut down the women's football league in 2003 for three seasons citing allegations of lesbian relationships among the players as one of the reasons. See S. Yıldız, "Ve Ben Bir Taraftarım Bağırmasam Olmaz," 2015, http://kaosgldergi.com/dosyasayfa. php?id=2844, accessed June 10, 2020. See also Hurriyet, "Halil İbrahim Dinçdağ TFF'ye Açtığı Davayı Kazandı."

38 "Turkey Bans Deniz Naki from Professional Football," January 30, 2018, http://www.dw.com/en/ turkey-bans-deniz-naki-from-professional-football/a-42370473, accessed June 10, 2020.

39 Interviewee 4: a non-binary football player in one of the queer-identified teams. 


\section{Resist through football}

The number of amateur football teams with different political agendas has increased in recent years and these teams use the football field as an instrument to convey their claims to the wider public. Football is not one of the determinant features of the resistance in this category; another kind of sports or even a completely different activity or space could be adopted as a tool instead of the football field, though whether the wide popularity of football has played a role in this particular choice is open to debate. Most of the teams in the alternative leagues might be counted in this category. While some fan groups often instrumentalize terraces in the professional football field, ${ }^{40}$ it can be stated that fields becoming the spaces of resistance in such a diverse and broad manner is a recent phenomenon. The queer-identified amateur football teams occasionally adopt this approach, as well. Seçkin: ${ }^{41}$

We discuss a lot in the team whether we are a football team or a community that does LGBTI+ politics. I think we are both. We play football, we play it very well. We also do politics. Showing that many women play football very well is also something that shatters the gender norms. In addition to this, we always have different things to raise when we enter the field. We send our messages through that field. Moreover, we sometimes organize friendly matches. All of these are politics.

The fact remains that this category is insufficient to explain the struggle of queer-identified amateur football teams. This instrumental approach to football does not challenge the status quo, which subordinates gender non-conforming individuals on and off the field. It neither brings a radical change to the social order nor motivates these individuals to exceed their limits since improving athletic skills becomes of secondary importance and it considers the game as a "social project." The increase in the projects fostering equality through football might easily benefit from the regulatory aspect of the game and thus reproduce the gender roles and inequalities in society. To avoid that, and

40 At this point I should mention the law numbered 6222 on "the Prevention of Violence and Disorder in Sport" that was passed in 2011 and the electronic ticketing system named Passolig that was introduced in 2014 despite widespread criticism and objections coming from the fans. These are two significant moments in the process of governmentalization of the football field through policing and information gathering in relation to the neoliberal policies of the state at every layer of public space (Nuhrat, "The Violence Law and the Governmentalization of Football in Turkey"). Since the institution of Passolig and the enactment of the law, fan groups are no longer anonymous communities who raise their political statements on the terraces but they are under constant surveillance which leads to a significant decrease in collective political action within the limits of the professional football field.

41 Interviewee 5: a lesbian football player in one of the queer-identified teams. 
thus to make the field a safer space for gender non-conforming bodies, laboring over the basics of the game is an urgent need.

Resist for football

As for the last category, the distance between the game and body disappears. Here, the footballing person is neither against football nor aiming to reach a further target through football, but someone whose resistance is mainly for being able to play football. The increasing interest of women and queers in football, in my opinion, distinctively belongs to the third category even though their politics on the field also speak to the other two categories. In the modern football field, which was created and spread around the world to affirm the superiority of the Western cisgender straight man, women and queers were positioned as the constituent other. Therefore, the recent orientation of gender non-conforming individuals toward the football field requires an explanation beyond the discourse of scalable inclusion. The last category that I propose, resistance for football, refers to the efforts made by the queer-identified teams to transgress the borders of the field which are not only material but also sexual (i.e., sexualized).

What carries the category of "resistance for football" beyond the discourse of scalable inclusion is its refusal of the host-guest dynamic and its efforts of collective space-making and refiguration of the game in harmony with the sexual and spatial orientations of the individuals. Instead of feeling allowed to enter a space, for what Ahmed calls "straight hospitality," 42 these newly emerging queer-identified football teams struggle for self-determination regarding their place, interactions, and bodies.

During the fieldwork, I collected narratives about the encounters that the players of the queer-identified teams had on the field with a variety of actors such as the other political opposition groups, cisgender straight men both in their team and in the opponent team, the managers of artificial turf, the other teams renting the field, and passers-by during the games. Interestingly, no matter whether these encounters were positive or negative, they often contained practices and performances which contribute to positioning the queer subject as the guest. While a negative example might be the discussion among the unofficial "hosts" of an alternative mixed league on whether a queeridentified team should be accepted in or not, a positive example might be that a queer-identified team finds a box of pastry in their locker room offered by the managers of the artificial turf as a sign of their hospitality.

42 Ahmed, Promise of Happiness. 


\section{Space-making and sexuality: football as a sexual orientation}

Space today is "understood to play an active role in the constitution and reproduction of social identities and, vice versa, social identities, meanings, and relations are recognized as producing material and symbolic or metaphorical spaces." 43 This reciprocal interaction also manifests itself in the production and reproduction of sexualized bodies and spaces. Rejecting the idea that the material characteristics of spaces predetermine internal power relationships is important because "it denaturalizes the presumed heterosexuality of everyday spaces." ${ }^{4}$ Ahmed, through the concept of a "straight line of life," draws an analogy between the linearity of life and being straight/heterosexual by claiming that a straight person's body is aligned with the progression of everyday life. This alignment erases the history and the effort behind straightening the things or "holding" them in place; things, aligned on the vertical axis, look like they were always straight. ${ }^{45}$ In light of all these, I argue that it is possible to speak of the presumed heterosexuality of the football field.

If a person, who is not a cisgender straight man, proves to be good at football they often encounter stereotypical assumptions and interventions about their sexuality and its expression on the field. As Öztürk states, the TFF makes efforts to highlight the femininity of women footballers, and the unwritten criterion of "having good manners" is required to be picked for the national team; these institutional efforts started with the restructuring process of women's football after the suspension of the league in 2003. Quoting the statements of administrators that refer to the "bad behaviors which ended women's football," Öztürk argues that there was the intention of breaking the equation between football, lesbianism, and masculinity. ${ }^{46}$ Leaving aside the futile efforts of seeking the truth in these stereotypes, I argue that our concern should be the effects that these stereotypes create in the lives, aptitudes, and decisions of women and gender non-conforming people. Most of my interviewees had childhood memories in which families or schools were afraid when the child had a liking for football. Yağmur ${ }^{47}$ said:

We were living in a housing estate and there were tennis lessons for children. My dad told me to quit playing football and start the tennis course because it is more suitable for girls. And my mom told me to play tennis, so she would buy me pretty skirts. I said that I don't have to wear skirts, but this became another problem.

43 Gill Valentine, "Queer Bodies and the Production of Space," in The Handbook of Lesbian and Gay Studies, edited by Diane Richardson and Steven Seidman (London: Sage, 2002) 146.

44 Ibid. 154.

45 Ahmed, Queer Phenomenology, 66.

46 Öztürk, "Kadın Futbolcuların Futbol Alanındaki Deneyimleri," 112-13.

47 Interviewee 6: a lesbian football player in one of the queer-identified teams. 
The stereotypical relationship between football and lesbianism not only creates anxiety in a child's surroundings but the children themselves sometimes move away from the football field for their heterosexual performance to be approved. Doğan ${ }^{48}$ remembered a moment from her adolescence during our interview. She stopped playing football in adolescence and also started to realize that she is not straight. In that period, she says, whenever a ball came toward her in the schoolyard she did not want to control it with her feet. She instead kneeled down and picked up the ball with her hands. She intuitively felt that if she revealed that she knew how to interact with the ball with her feet, she would also reveal her lesbianism. She described this feeling "as if my clothes would suddenly fall off." Ahmed states that "the directedness of the body toward an action (which we have discovered also means an orientation toward certain kinds of objects) is how the body 'appears"' and, drawing upon Merleau-Ponty's "habitual body," she claims that "the body is habitual insofar as it 'trails behind' in the performing of an action." ${ }^{\text {"9 }}$ Doğan's expression seems to be in line with habit given the fact that the word "habit" means clothing in Latin as well as condition and appearance; she performed the appropriate bodily action not to reveal what lies behind the habitual body.

The link between sexual and spatial orientations shapes the domain of what a body can do, both in terms of normativity and capacity. What Husserl and Merleau-Ponty describe as "sedimentation" "habitus" ${ }^{1}$ refer to the argument that histories of bodily (inter)actions inside a field affect the further possibilities, orientations, and tendencies of bodies. The resistance of queer-identified amateur football teams in Turkey reveals that the heterosexuality of the football field is neither natural nor ahistorical; the history behind its constitution makes it home for certain individuals while positioning the others as guests. Those who do not feel at home regulate their bodies accordingly, try to negotiate with the requirements, or disclaim those spaces. The sexuality politics on today's football field matter because they self-determine their spaces and this creates a shift in the ostensibly neutral and straight line. Miran ${ }^{52}$ describes the shift with these words: "Think about all the features attributed to genders, attributed to us. Similarly, football, which is actually just a game, has a lot of things that are constructed. And what we do through these teams is deconstructing them."

48 Interviewee 7: a lesbian football player in one of the queer-identified teams.

49 Ahmed, Queer Phenomenology, 130.

50 Anthony Steinbock, Home and Beyond: Generative Philosophy after Husserl (Evanston: Northwestern University Press, 1995), 36.

51 Pierre Bourdieu, Outline of a Theory of Practice (Cambridge: Cambridge University Press, 1977).

52 Interviewee 8: a non-binary football player in one of the queer-identified teams. 


\section{Queering the field and border-making}

The straight line of life targets success and happiness and the act of straightening this line renders it rough for queers to relate to what is presumed to be desired at the point of arrival. ${ }^{53}$ Halberstam argues that failing under certain conditions as well as losing, forgetting, and not knowing can offer much more creative, collective, and surprising ways of inhabiting the world. ${ }^{54}$ Heckert problematizes the same situation reversely: "What visions, what possibilities, what lives remain hidden when the mind is focused on, driven toward, success?" ${ }^{25}$ It is possible to adapt these words to the norms and regulations dominant on the football field. A score-oriented team draws a line with a clarified destination - regardless of the complexity of their tactics - which restricts the range of possible movements as well as the area they occupied on the field. The queer-identified teams analyzed in this study are also significant because they intervene in the value system of the game. Funda expresses her opinions about the notion of failure in general and states that the queer football field helped her relate to this notion differently:

Failure is something that I have been thinking about a lot recently; I am trying to make peace with failure, embrace it, not to give too much importance to it, and so on. The effort of not making a mistake makes me tired, and I feel very bad when I make a mistake. I've got to grips with this for a while now. And I learn a lot in football because this struggle is very visible there. When I see that we could create such an attentive alternative on the football field, I feel like we can do anything we want. What we do is not so easy I guess; realizing this makes me very powerful since it is something incredible that is created by the presence of each one of us.

The name of the football tournament held in Pride Week 2016 was "The Tournament of Those Who Like to Concede Goals" (Gol Yemeyi Sevenler Turnuvast) and almost all the queer-identified teams that existed at that time participated in the tournament. Many players emphasize that they act against a common enemy (i.e., ciscentric, heteronormative, and sexist structures of the field) in solidarity instead of rivaling each other. Ediz states: "as a team, we are not interested in scorekeeping at all; we don't even know the score most of the time. What matters for us is to play a good game, to have fun, to

53 Ahmed, Queer Phenomenology.

54 Halberstam, The Queer Art of Failure.

55 Jamie Heckert, "Intimacy with Strangers/Intimacy with Self: Queer Experiences of Social Research," in Queer Methods and Methodologies: Intersecting Queer Theories and Social Science Research, edited by Kath Browne and Catherine Nash, 41-54 (London: Ashgate, 2010), 42. 
create a space for a woman to liberate herself." In Queer Olympix, ${ }^{56}$ an annual sports event organized by one of the queer-identified teams called Atletik Dildoa, ${ }^{57}$ the winner of football matches is defined by five criteria: equal distribution of passes (team play), reckless and aggressive game (harsh tackles, hard shots, etc.), discriminatory language, scores (regardless of the number of goals scored, the side which scores most receives two points and the other side receives one point), and the points that teams give to each other. To make a fair assessment, each match is observed by two players from another team that is not playing. As can be seen, these scoring criteria reduce the importance of winning in a typical way almost to the level of zero, which is an intervention that shakes the ground of the field and thus the movements and orientations of the bodies inside.

These experiments are worth discussing because they pave the way for a new value system in the game. ${ }^{58}$ As Bourdieu stated, "a new way of practicing an already established sport [...] causes a restructuring of the space of sporting practices and a more or less complete redefinition of the meaning attached to the various practices. ${ }^{\prime 59}$ While these lively interventions in the conventional rules and values of football enable us to problematize the concept of "fair," it is necessary to be mindful of whether another set of values is proposed by them and thus some appropriate and inappropriate behaviors are defined. The concept of "queer commons" is crucial to insert at this point, which is defined by Özbay and Savc1 as "a radical rethinking of self and community, and thus a radical rethinking of belonging and the concept of commons itself." ${ }^{\prime 0}$ I consider it crucial to further reflect upon the processes of bonding, belonging, and border-making in queer communities, on whom we are welcoming and whom we leave aside, to be able to cultivate ethical ways of sharing the commons and of living together.

56 The Queer Olympix maintains a critical position in relation to the Olympic Games and other international mega sports events for many reasons, but first of all for their binary and competitive logic. The organizers also problematize the concept of fair play by experimenting with values, as seen in the scoring criteria.

57 See their Facebook page: https://www.facebook.com/atletikdildoa/, accessed December 12, 2019.

58 Football 4 Peace and football3 are among other examples of these experiments. For more info see https://www.streetfootballworld.org/football3/, accessed December 17, 2020. See also Jayne Caudwell and Graham Spacey, "Football 4 Peace versus (v) Homophobia: A Critical Exploration of the Links between Theory, Practice and Intervention," in Critical Research in Sport, Health and Physical Education: How to Make a Difference, edited by H. Larsson, G. Gerdin, and R. Pringle (London: Routledge, 2018), 39-51.

59 Pierre Bourdieu, "How Can One Be a Sports Fan?" in The Cultural Studies Reader, edited by Simon During (London: Routledge, 1993), 436.

60 Cenk Özbay and Evren Savcl, "Queering Commons in Turkey," GLQ: A Journal of Lesbian and Gay Studies 24, no. 4 (2018): 520. 


\section{Conclusion: contributions and promises}

Referring again to Bourdieu's conceptualization of "field," it can be claimed that the football field is one of the countless other fields in which people are constantly mobile and thus struggle never ends. ${ }^{61}$ The football field cannot be described as oppressive or emancipatory in itself. Considering the aspect of sexualities, instead of perceiving this field as a static environment where prediscursively fixed identities locate, I prefer to perceive it as a playing field that offers new spatial orientations and creative and unconventional (inter) actions for the bodies inside. That of queer-identified amateur football teams is not a struggle primarily to be included in the conventional football field but rather to deconstruct the centralized regulation of the game and to proliferate its potential for queer happenings that are only possible by setting the convenient conditions for the entrance of those who have been marginalized.

I conceive of this research as an attempt at disrupting the assumptions of football as a straightening tool and assumptions of the football field as a site of masculinity and compulsory heterosexuality. Consideration of the football field as a site of queer resistance and consideration of footballing bodies as resisting bodies can hopefully evoke unconventional ways for bodies to orient themselves on the field through which this space can become a site of queer happenings. A spatial analysis of gender non-conforming footballing people and the non-linear paths that these bodies follow presents the football field as a new spatial orientation that might carry the potential to disrupt and transform the game itself while creating new lines, new objects, and new spaces for the marginalized sexualities in Turkey.

The anthropology of sport is directly linked with debates on the limitations and potentials of the individual body. Since my research locates where this literature overlaps with sexuality studies, its contributions go beyond the football field. The analysis on the relationship between sexual and spatial orientations denaturalizes the heterosexuality of everyday spaces, challenges dualistic and stable gender categories, and problematizes antagonistic and success-oriented structures as obstacles to solidarity and creativity. The debate on queer commons and scalable inclusion probes the possibility of an ethical and non-hierarchical coexistence. With a cautious approach to processes of bonding, belonging, and border-making in queer communities, it investigates the means and methods of self-determination of places, interactions, and bodies.

61 Cited in Koca, "Cinsiyetlendirilmiş Bir Sosyal Alan Olarak Spor," 21. 


\section{References}

“Eşcinselliğin Mücadele Alanı Olarak Futbol.” December 14, 2013, http://bianet.org/biamag/lgbti/152047escinselligin-mucadele-alani-olarak-futbol, accessed October 12, 2019.

"Futbol Kadını Bozar mı." April 4, 2016, http://www.5harfliler.com/futbol-kadini-bozar-mi/, accessed July 18, 2020.

"Futbolun Kadınla İmtihanı." June 30, 2009, http://www.radikal.com.tr/yazarlar/tanil-bora/futbolunkadinla-imtihani-942886/, accessed July 24, 2020.

"Istanbul LGBTI+ Pride Committee Statement: We are Dispersing!" June 24, 2016, https:// LGBTInewsturkey.com/2016/06/24/istanbul-LGBTI-pride-committee-statement-we-are-dispersing/, accessed October 12, 2019.

“Turkey Bans Deniz Naki from Professional Football." January 30, 2018, http://www.dw.com/en/turkeybans-deniz-naki-from-professional-football/a-42370473, accessed June 10, 2020.

Ahmed, Sara. Queer Phenomenology: Orientations, Objects, Others. Durham, NC: Duke University Press, 2006.

—. Promise of Happiness. Durham, NC: Duke University Press, 2010.

Besnier, Niko. "Sports, Bodies, and Futures: An Epilogue." The Contemporary Pacific 26, no. 2 (2014): 435-44.

Besnier, Niko, Susan Brownell, and Thomas F. Carter. The Anthropology of Sport: Bodies, Borders, Biopolitics. Oakland: University of California Press, 2018.

Bourdieu, Pierre. Outline of a Theory of Practice. Cambridge: Cambridge University Press, 1977.

- Distinction: A Social Critique of the Judgement of Taste. London: Routledge, 1984.

. "How Can One Be a Sports Fan?" In The Cultural Studies Reader, ed. Simon During, 427-40. London: Routledge, 1993.

Caudwell, Jayne. "Queering the Field? The Complexities of Sexuality within a Lesbian-Identified Football Team in England." Gender, Place \& Culture 14, no. 2 (2007): 183-96.

Caudwell, Jayne and Graham Spacey. "Football 4 Peace versus (v) Homophobia: A Critical Exploration of the Links between Theory, Practice and Intervention." In Critical Research in Sport, Health and Physical Education: How to Make a Difference, ed. H. Larsson, G. Gerdin, and R. Pringle, 39-51. London: Routledge, 2018.

Drury, Scarlett. "Gay Sports Spaces: Transgressing Hetero (/Homo) Normativity and Transforming Sport?" In The Routledge Handbook of Sport, Gender and Sexuality, ed. Jennifer Hargreaves and Eric Anderson, 309-17. New York: Routledge, 2014.

Erel, Umut, Jin Haritaworn, Encarnación Gutiérrez Rodríguez, and Christian Klesse. "On the Depoliticisation of Intersectionality Talk: Conceptualising Multiple Oppressions in Critical Sexuality Studies." In Theorizing Intersectionality and Sexuality, ed. Y. Taylor, S. Hines, and M. E. Casey 56-77. Palgrave Macmillan, London, 2010.

Fasting, Kari. "Sporda Cinsel Taciz ve İstismar." In Oyunun Ötesinde, ed. İ. Hacısoftaoğlu, F. Akcan, and N. Bulgu, 211-30. Istanbul: Nota Bene, 2015.

FIFA, “Women's Football: Member Associations Survey Report." 2019, https://img.fifa.com/image/upload/ nq3ensohyxpuxovcovj0.pdf, accessed December 12, 2019.

Haber Vitrini, “Bayan Futbol Liginde Lezbiyenlik Skandalı." December 26, 2003, http://www.habervitrini. com/spor/bayan-futbol-liginde-lezbiyenlik-skandali-97636, accessed October 12, 2019.

Halberstam, Jack. The Queer Art of Failure. Durham, NC: Duke University Press, 2011.

Hargreaves, Jennifer. Sporting Females: Critical Issues in the History and Sociology of Women's Sports. London: Routledge, 1994.

Heckert, Jamie. "Intimacy with Strangers/Intimacy with Self: Queer Experiences of Social Research." In Queer Methods and Methodologies: Intersecting Queer Theories and Social Science Research, ed. Kath Browne and Catherine Nash, 41-54. London: Ashgate, 2010.

Horne, John. Sport in Consumer Culture. New York: Palgrave, 2005.

Human Rights Watch. "Turkey Events of 2018." 2019. https://www.hrw.org/world-report/2019/countrychapters/turkey, accessed October 12, 2019. 
Hurriyet, “Halil İbrahim Dinçdağ TFF'ye Açtığı Davayı Kazandı.” December 29, 2015, http://www.hurriyet. com.tr/halil-ibrahim-dincdag-tffye-actigi-davayi-kazandi-40033252, accessed October 12, 2019.

Karakaş, Burcu and Bawer Çakır. Erkeklik Ofsayta Düşünce. İstanbul: Illetişim, 2013.

Kay, Tess and Ruth Jeanes. "Women, Sport and Gender Inequity." In Sport and Society: A Student Introduction, ed. B. Houlihan and D. Malcolm, 130-54. London: Sage, 2015.

Knijnik, Jorge. "Femininities and Masculinities in Brazilian Women's Football: Resistance and Compliance." Journal of International Women's Studies 16, no. 3 (2015): 54-70.

Koca, Canan. "Cinsiyetlendirilmiş Bir Sosyal Alan Olarak Spor." In Sporun Toplumsal Cinsiyet Halleri, ed. Canan Koca, 18-37. Ankara: Spor Yayınevi, 2016.

Liston, Katie. "Sport and Gender Relations." Sport in Society 9, no. 4 (2006): 616-33..

Maguire, Joseph. Power and Global Sport. London: Routledge, 2005.

Nuhrat, Yağmur. "The Violence Law and the Governmentalization of Football in Turkey." In The Making of Neoliberal Turkey, ed. Cenk Özbay, Maral Erol, Z. Umut Türem, and Ayşecan Terzioğlu, 83-96. London: Routledge, 2016.

—. "Contesting Love through Commodification." American Ethnologist 45, no. 3 (2018): 392-404.

O'Reilly, Karen. Key Concepts in Ethnography. London: Sage, 2008.

Ong, Aihwa. "Women out of China: Traveling Tales and Traveling Theories in Postcolonial Feminism." In Women Writing Culture, ed. Ruth Behar and Deborah A. Gordon, 350-72. Berkeley: University of California Press, 1995.

Orta, Lale. "Women and Football in Turkey." International Journal of Humanities and Social Science 47, no. 1 (2014): 85-93.

Öktem, Kerem and Karabekir Akkoyunlu. "Exit from Democracy: Illiberal Governance in Turkey and beyond." Southeast European and Black Sea Studies 16, no. 4 (2016): 469-80.

Özbay, Cenk, Maral Erol, Aysecan Terzioglu, and Z. Umut Türem. The Making of Neoliberal Turkey. London: Routledge, 2016.

Özbay, Cenk and Evren Savcı. "Queering Commons in Turkey." GLQ: A Journal of Lesbian and Gay Studies 24, no. 4 (2018): 516-21.

Öztürk, Pınar. "Kadın Futbolcuların Futbol Alanındaki Deneyimleri." Unpublished PhD dissertation, Hacettepe University, 2017.

Pfister, Gertrud. "Avrupa Perspektifinden Toplumsal Cinsiyet ve Spora İlişkin Gelişmeler ve Mevcut Sorunlara bir bakış." In Oyunun Ötesinde, ed. I. Hacısoftaoğlu, F. Akcan, and N. Bulgu, 159-86. Istanbul: Nota Bene, 2015.

Robidoux, Michael A. "Historical Interpretations of First Nations Masculinity and Its Influence on Canada's Sport Heritage." The International Journal of the History of Sport 23, no. 2 (2006): 267-84.

Sehlikoglu, Sertaç. "Sports: Turkey." In Encyclopedia of Women and Islamic Cultures, Vol. 14, ed. Suad Joseph and Elora Shehabuddin. Leiden: Brill, 2017.

Steinbock, Anthony. Home and Beyond: Generative Philosophy after Husserl. Evanston: Northwestern University Press, 1995.

Tsing, Anna. "On Nonscalability: The Living World Is Not Amenable to Precision-Nested Scales." Common Knowledge 18, no. 3 (2012): 505-24.

Vaczi, Mariann. "Dangerous Liaisons, Fatal Women: The Fear and Fantasy of Soccer Wives and Girlfriends in Spain." International Review for the Sociology of Sport 51, no. 3 (2016): 299-313.

Valentine, Gill. "Queer Bodies and the Production of Space." In Handbook of Lesbian and Gay Studies, ed. Diane Richardson and Steven Seidman, 145-60. London: Sage, 2002.

Yarar, Betül. "Modernleşmenin Gerilimlerle Dolu Kimliği: Modern Türkiye Tarihinde Hem Kadın Hem Sporcu Olmak." Oyunun Ötesinde, ed. İlknur Hacısoftaoğlu, Funda Akcan, and Nefise Bulgu, 187-210. İstanbul: Nota Bene, 2015.

Yıldız, S. "Ve Ben Bir Taraftarım Bağırmasam Olmaz." 2015, http://kaosgldergi.com/dosyasayfa.php?id= 2844, accessed June 10, 2020. 